\title{
Utility of nintedanib for severe idiopathic pulmonary fibrosis: a single-center retrospective study [Letter]
}

This article was published in the following Dove Medical Press journal:

Drug Design, Development and Therapy

\section{Leticia Orsatti \\ Josep Fortea \\ Manuel Quaresma}

Boehringer Ingelheim International $\mathrm{GmbH}$, Ingelheim, Germany
Correspondence: Manuel Quaresma Boehringer Ingelheim International $\mathrm{GmbH}$, Binger Str. 173, Ingelheim am Rhein 55216, Germany

Tel +496I3277 I43 I24 Email manuel.quaresma@boehringeringelheim.com

\section{Dear editor}

We read with interest the study by Abe et al on the clinical utility of nintedanib in patients with severe idiopathic pulmonary fibrosis (IPF). ${ }^{1}$ Based on the retrospective follow-up of 51 patients, the authors concluded that the survival benefit from nintedanib is reduced among patients with severe IPF $(n=17)$ compared with those with mild-to-moderate IPF $(n=34)$, but that the prognosis for patients with severe IPF is significantly better in those who remain on nintedanib for more than 3 months.

In our opinion, the study design does not allow conclusions to be drawn about the treatment effect of nintedanib on survival in patients with severe versus mild-tomoderate IPF. First, the two study groups present clinically meaningful differences at baseline; for example, mean body weight was significantly lower in patients with severe IPF (and body weight loss is associated with decreased survival time). ${ }^{2}$ Second, a higher mortality rate among patients with severe IPF was to be expected independent of any pharmacological intervention, as lower FVC and lower diffusing capacity of the lungs for carbon monoxide $\left(\mathrm{DL}_{\mathrm{CO}}\right)$ at baseline have been associated with a worse prognosis. ${ }^{3}$ In addition, the study shows that patients with severe IPF had a greater FVC decline than those with mild-to-moderate IPF in the year before nintedanib administration. A higher decline in FVC over time has also been associated with a worse prognosis. ${ }^{3}$ In the absence of an appropriate design (ie, a prospective, randomized, and placebo-controlled study), no definite conclusions can be drawn on the survival effects of nintedanib in patients with severe IPF.

The data presented by Abe et al show that initiation of nintedanib (150 mg twice daily) resulted in slower FVC decline in both mild-to-moderate and severe IPF populations, which suggest a beneficial effect of nintedanib independent of disease severity. These findings are consistent with data from the open-label extension trial INPULSIS-ON (NCT01619085) ${ }^{4}$ and the INSTAGE trial (NCT02802345), ${ }^{5}$ both of which suggest that IPF patients with more advanced functional impairment may receive the same benefit from nintedanib on reduction in FVC decline as those with less severe impairment. Furthermore, recently published real-world data from Korea ${ }^{6}$ and Greece $^{7}$ also demonstrate that nintedanib reduces the rate of FVC decline in patients with more advanced IPF ( $\mathrm{FVC} \leq 50 \%$ or $\mathrm{DL}_{\mathrm{CO}} \leq 35 \%$ predicted).

Abe et al showed that survival was improved in patients with severe IPF who remained on nintedanib for more than 3 months, suggesting that permanence on treatment is an important therapeutic goal. As highlighted by Abe et al, management of adverse events related to nintedanib, as recommended in the prescribing information 
(including symptomatic treatment of diarrhea and close monitoring of liver enzyme levels), has the potential to allow patients to remain on treatment and derive long-term therapeutic benefits. Indeed, the adoption of a holistic approach to patient management, including nurse support and possible dosage adjustment, is important to maintain compliance and optimize long-term outcomes.

In conclusion, findings from real-world studies, even those lacking a control group or involving relatively few patients, can provide valuable clinical insights but should be interpreted in the context of data from large, randomized controlled clinical trials. The results reported by Abe et al reinforce the need for adequate adverse event management and suggest that nintedanib slows down disease progression independent of disease severity.

\section{Disclosure}

LO, JF, and MQ are employees of Boehringer Ingelheim. The authors report no other conflicts of interest in this communication.

\section{References}

1. Abe M, Tsushima K, Sakayori M, et al. Utility of nintedanib for severe idiopathic pulmonary fibrosis: a single-center retrospective study. Drug Des Devel Ther. 2018;12:3369-3375. doi:10.2147/DDDT

2. Nakatsuka Y, Handa T, Kokosi M, et al. The clinical significance of body weight loss in idiopathic pulmonary fibrosis patients. Respiration. 2018;96:338-347. doi:10.1159/000489474

3. Ley B, Collard HR, King TE. Clinical course and prediction of survival in idiopathic pulmonary fibrosis. Am J Respir Crit Care Med. 2011;183: 431-440. doi:10.1164/rccm.201006-0894CI

4. Wuyts WA, Kolb M, Stowasser S, Stansen W, Huggins JT, Raghu G. First data on efficacy and safety of nintedanib in patients with idiopathic pulmonary fibrosis and forced vital capacity of $\leq 50 \%$ of predicted value. Lung. 2016;194:739-743. doi:10.1007/s00408-016-9912-1

5. Kolb M, Raghu G, Wells AU, et al. Nintedanib plus sildenafil in patients with idiopathic pulmonary fibrosis. N Engl J Med. 2018;379:1722-1731.

6. Yoon HY, Park S, Kim DS, Song JW. Efficacy and safety of nintedanib in advanced idiopathic pulmonary fibrosis. Respir Res. 2018;19:203. doi:10.1186/s12931-018-0907-8

7. Tzouvelekis A, Karampitsakos T, Kontou M, et al. Safety and efficacy of nintedanib in idiopathic pulmonary fibrosis: a real-life observational study in Greece. Pulm Pharmacol Ther. 2018;49:61-66. doi:10.1016/j. pupt.2018.01.006

Dove Medical Press encourages responsible, free and frank academic debate. The content of the Drug Design, Development and Therapy 'letters to the editor' section does not necessarily represent the views of Dove Medical Press, its officers, agents, employees, related entities or the Drug Design, Development and Therapy editors. While all reasonable steps have been taken to confirm the content of each letter, Dove Medical Press accepts no liability in respect of the content of any letter, nor is it responsible for the content and accuracy of any letter to the editor.

\section{Publish your work in this journal}

Drug Design, Development and Therapy is an international, peerreviewed open-access journal that spans the spectrum of drug design and development through to clinical applications. Clinical outcomes, patient safety, and programs for the development and effective, safe, and sustained use of medicines are the features of the journal, which has also been accepted for indexing on PubMed Central. The manuscript management system is completely online and includes a very quick and fair peer-review system, which is all easy to use. Visit $\mathrm{http}: / /$ www.dovepress.com/testimonials.php to read real quotes from published authors. 